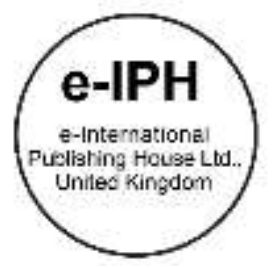

\title{
Antecedents Associated with Waste Management in the Oil and Gas Industry
}

\author{
Saripah Abdul Latif, Tengku Amira Yasmin Tengku Iskandar
}

\author{
Faculty of Business and Management, \\ Universiti Teknologi MARA Kota Bharu Campus, Lembah Sireh, Kota Bharu 15050 Malaysia \\ saripah5998@gmail.com, tengkuamirayasmin@gmail.com \\ Tel: +60129294669
}

\begin{abstract}
Improper waste management during operational activities in the oil and gas industry brings adverse environmental impacts. Consequently, the quality of life of the population decreases. This study aims to investigate the antecedents for waste management in the oil and gas industry. Policy governance, facilities, technology and environmental education, are proposed to be affecting the waste management in the industry. Primary data was collected via an online survey among 98 oil and gas players in Malaysia. Policy governance, facilities and environmental education were found to be the antecedents, while technology is proven to be non-significance.
\end{abstract}

Keywords: Waste management; Policy governance; Facilities; Environmental education

eISSN: 2398-4287 @ 2019. The Authors. Published for AMER ABRA cE-Bs by e-International Publishing House, Ltd., UK. This is an open access article under the CC BYNC-ND license (http://creativecommons.org/licenses/by-nc-nd/4.0/). Peer-review under responsibility of AMER (Association of Malaysian Environment-Behaviour Researchers), ABRA (Association of Behavioural Researchers on Asians) and cE-Bs (Centre for Environment-Behaviour Studies), Faculty of Architecture, Planning \& Surveying, Universiti Teknologi MARA, Malaysia.

DOI: https://doi.org/10.21834/e-bpj.v4i10.1634

\subsection{Introduction}

Oil and gas industry is known to be one of the sectors that contribute environmental impacts to the world. Operational activities associated with petroleum production in oil and gas industry bring adverse impacts to the environment and may result in air pollution, contamination of water bodies, ground-water pollution, shortage of land for waste disposal and potential financial liabilities. Due to improper waste management, the conditions worsen which consequently lowers the quality of life of the population. The increase in consumption of petroleum products has obvious implications for the operations of the petroleum industry, including the risks posed to the natural environment and human safety (Ambituuni et al., 2014). One of the activities associated with this industry that brings environmental impacts is waste treatment. The waste treatment brings adverse life-cycle environmental impacts including the amounts of water and electricity consumed, treated water discharged and toxic emissions produced (Gonzalez, 2015).

The definition for waste management is the collection, transport, recovery and disposal of waste, including the supervision of such operations and the after-care of disposal sites, and including actions taken by a dealer who purchases and subsequently sells waste or a broker who acts on behalf of others in arranging recovery or disposal of waste (Gonzalez, 2015). Although waste management is crucial in the oil and gas exploration and production activities, it also brings hazards to the environment. The majority of waste streams are treated off-site, but there can be life cycle effects on the environment including the amounts of water and electricity consumed, treated water discharged and toxic emissions produced, which are due to oil refining operations (Gonzalez, 2015). Most oil and gas companies use landfilling to manage waste disposal treatment. However, this waste treatment method has its adverse impacts as it may contaminate the ground-water when the waste leached into the soil. Based on research conducted by Funmilayo (2014), the "sticky" nature of the waste enabled it to accumulate and threaten the environment if it is not managed. On the other hand, Funmilayo (2014), defined waste management as the collection, transportation and disposal of garbage sewage and other waste products

eISSN: 2398-4287 C 2019. The Authors. Published for AMER ABRA cE-Bs by e-International Publishing House, Ltd., UK. This is an open access article under the CC BYNC-ND license (http://creativecommons.org/licenses/by-nc-nd/4.0). Peer-review under responsibility of AMER (Association of Malaysian Environment-Behaviour Researchers), ABRA (Association of Behavioural Researchers on Asians) and cE-Bs (Centre for Environment-Behaviour Studies), Faculty of Architecture, Planning \& Surveying, Universiti Teknologi MARA, Malaysia.

DOI: https://doi.org/10.21834/e-bpj.v4i10.1634 
Since this study took place in Malaysia, there were also problems highlighted in the Malaysian oil and gas industry regarding poor waste management. The biggest issue that limits the waste management practices in the petroleum industry in Malaysia is the lack of practices on petroleum waste management (Lodungi et al., 2016). The authors further stated that petroleum waste management is not done intensively in Malaysia due to lack of knowledge on petroleum waste management, less encouragement from agencies that manage petroleum wastes, deficit of petroleum waste management technology in Malaysia, inferiority of commitments from petroleum waste management party and finally the cost of the petroleum waste treatment.

This study aims to identify the antecedents associated with waste management in the oil and gas industry in Malaysia. There are four research objectives to facilitate the researchers in finding ways of managing waste generated in the operational activities associated with petroleum production in the oil and gas industry.

The research objectives are;

i. To study the relationship between policy governance and waste management in the oil and gas industry

ii. To determine whether facilities influence waste management in the oil and gas industry

iii. $\quad$ To investigate if technology affects waste management in the oil and gas industry

iv. To determine whether environmental education impacts waste management in the oil and gas industry

These objectives are constructed after literatures pertaining to issues related to waste management in the oil and gas industry are reviewed and analyzed as described below.

\subsection{Literature Review}

In the literature study of this research, the problems arising in the waste management in the oil and gas industry are found to be due to lack of facilities in certain countries. As an example, in the Niger Delta, most of the facilities on the ground are obsolete as most of the pipes have been operating at full capacity which has exceeded the life span (Ibem-Ezera, 2010). This is because pipes that have operated above the installed capacity ought not to be in usage or in commercial applications as it may lead to ruptures and explosions, and so waste will be created. According to Zhao (2017), one of the causes of failure of policies enforcement in waste management in the Philippines is due to lack of sufficient infrastructure in inner provinces which makes it inefficient and ineffective to handle waste management. In Nigeria, the unavailability of waste treatment facility constitutes a serious dilemma in the management of waste streams (Derefaka, 2014). The author further mentioned that Nigerian waste management adopted the use of host community contractors to enhance local content, but there are issues with the compliance with standards.

According to the findings by Lodungi (2014), managing the waste produced must comply with the regulation and legislation act according to the primary petroleum industry law in Malaysia such as Petroleum Development Act 1974, Petroleum Regulation 1974, Gas Supply Act 1993 and Environmental Quality Act 1974. Ugochukwu (2008) stated that one of the factors responsible for several environmental problems in Nigeria according to UNDP Nigeria (2006) is the general inability of the agencies responsible for the environment to enforce laws and regulations, particularly with respect to urban planning and development, prospecting for minerals and adherence to industrial standards, sitting of public buildings and residential quarters in flood-prone areas, unsettled dump sites improperly reclaimed and converted to plots for erection of residential quarters, public buildings and market stalls in ecologically sensitive areas. When there are no proper legislations, waste production in the oil and gas industry may increase. Government failure leads to the implementation of inappropriate policies, poor policy construct, ignorance of the effects of policies and incomplete information (Ibem-Ezera, 2010).

Developing countries, especially those densely populated Asian countries with a lower gross domestic product (GDP), like the Philippines, Malaysia, Thailand and Sri Lanka, are experiencing a lack of resources to afford expensive technologies for solid waste management (Zhao, 2017). The author further stated that technologies successfully used in developed countries may only result in a greater debt in developing countries instead of a solution. The Philippines for instance, is a low-middle-income developing country. A lack of capital can be a barrier to apply waste-to-energy (WtE) technologies (Zhao, 2017). Thus, a waste management with proper technology is needed for those countries.

According to the United States Environmental Protection Agency (EPA) website, environmental education (EE) is a process that allows individuals to explore environmental issues, engage in problem solving, and take actions to improve the environment. Implementation of EE will help raise awareness among the residents of the country about how important it is to conserve the environment. It will trigger them to take actions and be more responsible towards the environment. EE is crucial for the management of waste disposal, especially in the oil and gas industry which contributes major pollution to the world at large and thus lowers the quality of life. Mwiinga (2014), stated that the high generation of waste entails that source reduction as a waste management strategy is important hence the need to change people's attitudes through $\mathrm{EE}$. As a result, environmental education and awareness in the areas of pollution control and waste management became increasingly important from a global perspective of resource management (Agunwamba, 1998). In Zambia, a study by Sichaaza (2009) found that waste was found all over public places due to lack of knowledge and negative attitudes towards waste management. They possessed negative attitudes due to lack of education and subject matter on waste management (Mwiinga, 2014). 


\subsection{Methodology}

In this study, the researchers used a descriptive conclusive research. The reason for choosing this method is to ensure specific hypotheses can be tested and relationships between variables can be examined. Based on the literature review, four alternative hypotheses $(\mathrm{H} 1)$ were formulated;

$\mathrm{H}_{1}$ : There is a significant relationship between policy governance and waste management in the oil and gas industry

$\mathrm{H} 12_{2}$ : There is a significant relationship between facilities and waste management in the oil and gas industry

$\mathrm{H}_{1}$ : There is a significant relationship between technology and waste management in the oil and gas industry

$\mathrm{H} 14_{4}$ : There is a significant relationship between environmental education and waste management in the oil and gas industry

To be able to test the hypotheses, data needs to be collected. Primary data was collected by using questionnaires as the instrument. The researchers carried out quantitative analysis to determine the relationships between the variables and tested the hypotheses to ascertain the antecedents of waste management in the oil and gas industry. Below are the details of the methodology used.

\subsection{Sample and Procedure}

The population for this research is the oil and gas industry players in Malaysia. They are the people who are directly involved in the production of petroleum in the oil and gas industry. However, the exact figure of the population cannot be determined as it does not have definite sampling frame. The respondents for this research were individuals representing the population of the oil and gas industry in Malaysia. A non-probability convenience sampling technique was used for sampling procedure. The researchers targeted 100 respondents to gain more accurate information from the respondents since they are the industry players who are more alert with the unsolved problem of poor waste management. Initially, the number of target respondents used in this research was 100 respondents of oil and gas industry players and those who are related to the industry. However, after screening the questionnaires collected, two sets have to be discarded as they were incomplete. Therefore, only 98 sets of questionnaires were left to be used for the data analyses.

\subsection{Variables Measurement}

In this research, the researchers used nominal and ordinal scales to measure the demographic variable section which is Section $F$ (Demographic Information) from the questionnaires. Nominal scale allows the researchers to categorize the subjects into certain groups. It is something that cannot be measured and scaled. On the other hand, Likert and interval scales were used for the rest of the sections which are Section A (Waste Management), Section B (Policy Governance), Section C (Facilities), Section D (Technology) and Section $\mathrm{E}$ (Environmental Education).

Reliability analysis for the items in the questionnaires was measured by using Cronbach 's alpha, to indicate the reliability and relevance of the questionnaires. The Cronbach's alpha values for all the items in the questionnaires are greater than 0.6. This shows that all the items are acceptable and some are good.

The questionnaires were distributed personally by the researchers. Apart from the close-ended items mentioned above, some openended questions were also thrown at the respondents. For example "What are your suggestions pertaining to the methods used in the waste treatment. ..?"

Once the data is collected and prepared, a descriptive analysis was first carried out, followed by Pearson correlation for association measurement. Then, for the purpose of hypotheses testing, a multiple regression was run.

\section{Proposed Multiple Regression Model}

Waste management $=\alpha+\beta_{1}$ (policy governance $)+\beta_{2}$ (facilities) $+\beta_{3}$ (technology) $+\beta_{4}$ (environmental education)

Where;

$a=$ coefficient for the constant

$\beta_{1}=$ coefficient for policy governance

$\beta_{2}=$ coefficient for facilities

$\beta_{3}=$ coefficient for technology

$\beta_{4}=$ coefficient for environmental education

Limitations do exist in this study. The sampling technique used is convenient sampling which is not very accurate. If a sampling frame is available, it would have been better to use a probability sampling such as stratified or cluster sampling.

\subsection{Findings}

The sample consists of 56.1 percent males and 43.9 percent females. These proportions represent the oil and gas industry in Malaysia, where the number of male workers is more than the females. Majority of the respondents are degree holders in their twenties and 51 percent comes from middle level or executive positions. 34.7 percent has 2 - 5 years of working experience while 20.4 percent are having $6-10$ years of experience in the industry.

When a Pearson correlation test was carried out, the result shows that policy governance, facilities and environmental education have strong associations with waste management, whilst technology is only moderately correlated.

Hypotheses testing was carried out by running multiple regression. 
Table 1. Hypotheses Testing Results

\begin{tabular}{|c|c|c|}
\hline Hypothesis & $p$-value & Result \\
\hline $\begin{array}{l}\mathrm{H} 1_{1}: \text { There is a significant relationship between } \\
\text { policy governance and waste management in the oil } \\
\text { and gas industry in Malaysia }\end{array}$ & 0.001 & supported \\
\hline $\begin{array}{l}\mathrm{H} 1_{2} \text { : There is a significant relationship between } \\
\text { facilities and waste management in the oil and gas } \\
\text { industry in Malaysia }\end{array}$ & 0.003 & supported \\
\hline $\begin{array}{l}\mathrm{H} 1_{3} \text { : There is a significant relationship between } \\
\text { technology and waste management in the oil and } \\
\text { gas industry in Malaysia }\end{array}$ & 0.251 & Not supported \\
\hline $\begin{array}{l}\mathrm{H} 1_{4} \text { :There is a significant relationship between } \\
\text { environmental education and waste management in } \\
\text { the oil and gas industry in Malaysia }\end{array}$ & 0.016 & supported \\
\hline
\end{tabular}

Based on Table1 above, the result shows there are three supported alternative hypotheses which are $\mathrm{H} 1, \mathrm{H} 2$ and $\mathrm{H} 4$. The $\mathrm{p}$-value for $\mathrm{H}_{1}$ is 0.001 , for $\mathrm{H}_{2}$ is 0.03 and for $\mathrm{H}_{4}$ is 0.036 . The p-value for $\mathrm{H}_{3}$ is 0,251 , which is greater than 0.05 , and that makes technology a non-significant independent variable for waste management in the oil and gas industry. Therefore, there are three variables with significant results which are policy governance, facilities and environmental education. Another variable which is technology, is found to be not significant.

The calculated multiple regression model is as below :

Waste management $=0.502+0.293$ (policy governance $)+0.284$ (facilities $)+0.092$ (technology $)+0.237$ (environmental education)

The coefficient values show the relationships between the four independent variables with the dependent variable, which is waste management. The most influencing variable for waste management in the oil and gas industry is policy governance (coefficient $=0.293$ ), while the least influencing independent variable is technology (coefficient $=0.092$ ). These results confirm the findings of the hypotheses testing in Table 1 above.

\subsection{Discussion}

According to the hypotheses testing, the relationship between policy governance and waste management in the oil and gas industry in Malaysia is significant. Meaning to say the enforcement of the government rules and regulations to meet waste disposal requirement are well followed. Policy governance is adhered to by great companies such as PETRONAS (national petroleum company), Shell and other international petroleum companies that are operating in Malaysia. However, oil and gas companies should have policy, rules and regulations, standards and procedures, and departments that monitor the implementation and follow the right steps to keep the environment safe. This is because there are several areas that do not appear to have specific requirements such as ground-water monitoring, air monitoring and post- closure monitoring. The verification process in the handling of waste management is also needed to be implemented from factory to end place to ensure that the procedures are well followed. Most of the respondents stated that there is already the establishment of the policy and regulations, but the implementation is the challenge since improvising needs to be carried out.

In terms of facilities, authorised companies which have a license that meets the standard requirement should handle the location for waste disposal. The standards in the waste management for the oil and gas industry are already very high and are currently implemented. Somehow facilities need to be enhanced as they are as important as the issue itself.

Education is fundamental to develop responsibility and awareness. It has to start as early as possible to enlighten the importance of sustaining and cleaning the environment for better living and enhancement of the quality of life. All levels of management in the oil and gas companies should be given environmental education. All personnel in the oil and gas industry who are into waste management will always be required good induction with the process before entering the site to carry out the job.

\subsection{Conclusion and Recommendations}

Oil exploration and production have negatively impacted the environment of the host communities, by the generation of hazardous wastes and its inefficient disposal. This research study was undertaken to create better understanding and spread awareness of the antecedents associated with waste management in the oil and gas industry in Malaysia. The dependent variable for this research is waste management in the oil and gas industry in Malaysia. Meanwhile, the independent variables are policy governance, facilities, technology and environmental education. A conclusive descriptive study was carried out. A survey was undertaken to obtain primary data with the distribution of questionnaires among oil and gas players in Malaysia. The significant variables are found to be the policy governance, facilities and environmental education. Meanwhile, there is only one variable that is found to be not significant, which is technology

Based on findings and suggestions from the oil and gas players gathered in this study, it seems that a lot of people only know the surface of the waste management but not in details. Although there is practice of waste management by oil and gas companies in Malaysia, they need more agencies in handling waste management to ensure better waste management is being practised by the 
industry in Malaysia as there are limited companies that provide services of waste management in Malaysia. The respondents opined that Malaysia has high technology and competitive prices for waste management in the oil and gas industry. The cost is high to acquire advanced waste management technology. On the bright side, high technology offers better outcomes. Since Malaysia has the capability and the know-how in handling waste, the rate needs to be controlled to avoid overpricing resulting in reluctance in the engagement of waste management organisation.

In this research, there is one non-significant antecedent which is technology. The suggestion is in future research, more literature have to be studied to enlighten more possible variables for waste management in the oil and gas industry. The government and policy-makers, especially in Malaysia could use the findings of this research, to ensure a more effective and responsible waste disposal management, hopefully. Quality of life could not be achieved with degrading environmental conditions. Since the past studies for this issue were mostly limited to industrialised nations, the recommendation is to carry out more researches in other developing countries, with bigger sample sizes and to obtain the confirmation for this study.

\section{Acknowledgements}

The authors wish to acknowledge the cooperation and participation of the oil and gas industry players in Malaysia who have contributed to the success of this research.

\section{References}

Agunwamba, J. Environmental Management (1998) 22: 849. https://doi.org/10.1007/s002679900152. DOI https://doi.org/10.1007/

Ambituuni, A. (2014). A Risk Management Framework for Downstream Petroleum Product Transportation and Distribution in Nigeria. Retrieved 22 October, 2017, from https://www.researchgate.net/profile/Ambisisi_Ambituuni/publication/312498915_A_risk_m

anagement_framework_for_downstream_petroleum_product_transportation_and_distribution_in_Nigeria/links/587f998808ae9275d4ee3637/A-risk-managementframework-for-downstream

Derefaka, J. (2014). Waste Management Challenges in the Oil \& Gas Industry with Special Focus on Limited Disposal Infrastructures: Shell Companies in Nigeria (SCiN) Challenges and Lessons Learnt. 10.13140/RG.2.1.2184.2965.

Funmilayo, A. T. (June, 2014). Assessment of Solid Waste Management in Samaru Zaria, Nigeria.Retrieved 30 August, 2017, from http://kubanni.abu.edu.ng:8080/jspui/bitstream/123456789/6081/1/ASSESSMENT\%200F\%2 0SOLID\%20WASTE\%20MANAGEMENT\%20IN\%20SAMARU\%20ZARIA\%2C\%20NIG ERIA.pdf

Gonzalez, G. (November, 2015). Sustainability and Waste Management: A Case Study on an UK Oil Refinery during Day-to-day and Turnaround Operations. Retrieved 30 August, 2017, from http://epubs.surrey.ac.uk/810016/1/MPhil\%20Thesis\%20Gledys\%20Gonzalez.pdf

Ibem-Ezera, V. (May, 2010). Environmental Control in Oil \& Gas Exploration \& Production: A Case Study of the Niger Delta Region of Nigeria, West Africa. Retrieved 10 October, 2017

Lodungi, J. F., Alfred, D., Mohd Khirulthzam, A. F., Adnan, F. F., \& Tellichandran, S. (14 December, 2016). A Review in Oil Exploration and Production Waste Discharges According to Legislative and Waste Management Practices Perspective in Malaysia. Retrieved 1 September, 2017, from https://www.omicsonline.org/open-access/a-review-in-oil-exploration- and-production-waste-discharges-according-tolegislative-and-waste-management-practicesperspective-in-2252-5211-1000260.php?aid=85302\#18

Mwiinga, F. (2014). Perceptions of Solid Waste Management and the role of Environmental Education among Selected Residents of Choma Township of Southern Zambia. Retrieved 30 August, 2017, from http://dspace.unza.zm:8080/xmlui/bitstream/handle/123456789/3792/Main\%20Document.pdf

Sichaaza, H. M. (2009). An Assessment of Knowledge Attitudes and Practices towards Waste Management among Ng'ombe Residents. Retrieved 22 October, 2017

Ugochukwu, C. N. (29 September, 2008). Sustainable Environmental Management in the Niger Delta Region of Nigeria: Effects of Hydrocarbon Pollution on Local Economy. Retrieved 10 October, 2017

United States Environmental Protection Agency (2002). Exemption of Oil and Gas Exploration and Production Wastes from Federal Hazardous Waste Regulations. Retrieved 10 October, 2017, https://yosemite.epa.gov/oa/eab_web_docket.nsf/Attachments $\% 20$ By $\% 20 \mathrm{ParentFilingld} / 945$ EF425FA4A9B4F85257E2800480C65/\$FILE/28\%20-\%20RCRA\%20E\%26P\%20Exemption.pdf

Zhao, Y. (2017). Municipal Solid Waste Management and Waste to Energy Possibilities in thePhilippines. Retrieved 30 August, 2017, from https://www.doria.fi/bitstream/handle/10024/136223/Yilin\%20Zhao-Master\%27s\%20thesis.pdf?sequence=3 